\title{
First study on the helminth community structure of the neotropical marsupial Metachirus myosuros (Didelphimorphia, Didelphidae)
}

\author{
Primeiro estudo sobre a estrutura da comunidade de helmintos do marsupial \\ neotropical Metachirus myosuros (Didelphimorphia, Didelphidae)
}

Bruna Silva Cirino; Sócrates Fraga da Costa Neto²; Arnaldo Maldonado Júnior ${ }^{1}$; Rosana Gentile ${ }^{1 *}$ (D)

'Laboratório de Biologia e Parasitologia de Mamíferos Silvestres Reservatórios - LABPMR, Instituto Oswaldo Cruz, Fundação Oswaldo Cruz - FIOCRUZ, Rio de Janeiro, RJ, Brasil

${ }^{2}$ Campus Fiocruz Mata Atlântica - CFMA, Fundação Oswaldo Cruz - FIOCRUZ, Rio de Janeiro, RJ, Brasil

How to cite: Cirino BS, Costa Neto SF, Maldonado Júnior A, Gentile R. First study on the helminth community structure of the neotropical marsupial Metachirus myosuros (Didelphimorphia, Didelphidae). Braz J Vet Parasito/ 2020; 29(3): e005420. https://doi. org/10.1590/S1984-29612020064

\begin{abstract}
Metachirus myosuros is a marsupial species widely distributed in South America. Despite this, there is a lack of knowledge about its helminth parasites and helminth community structure. The aims of this study were to describe the species composition and determine the parasitological parameters of helminth communities of M. myosuros in preserved areas of the Atlantic Forest, Igrapiúna, Bahia state, northeastern Brazil. Parasites were searched from 19 specimens of this marsupial (18 were infected with at least one species), counted and identified. Ten species of helminth parasites were obtained: 7 nematodes, 2 platyhelminths and 1 acanthocephalan. The most abundant species were Aspidodera raillieti, Cruzia tentaculata, Physaloptera mirandai and Viannaia conspicua (Nematoda). These species were also the only dominant ones in the component community. Male hosts had higher prevalence of $P$. mirandai and greater abundance of $V$. conspicua. We observed a relationship between host body size and helminth abundance in both male and female hosts, and between host body size and helminth species richness in female hosts. This was the first study to analyze the helminth fauna and helminth community structure of M. myosuros. This was the first report of occurrences of $A$. raillieti and Didelphonema longispiculata in M. myosuros.

Keywords: Atlantic Forest, Brazil, Nematoda, parasite ecology, parasitism.

Resumo

Metachirus myosuros é uma espécie de marsupial amplamente distribuída na América do Sul. Apesar disso, existe pouca informação sobre seus helmintos parasitos e estrutura da comunidade de helmintos. Os objetivos deste estudo foram descrever a composição e determinar os parâmetros parasitológicos em comunidades de helmintos de M. myosuros, em áreas preservadas de Mata Atlântica, Igrapiúna, Bahia, Nordeste do Brasil. Os parasitos foram procurados em 19 espécimes desse marsupial (18 estavam infectados com pelo menos uma espécie), contados e identificados. Dez espécies de helmintos foram coletadas: 7 nematoides, 2 platelmintos e 1 acantocéfalo. As espécies mais abundantes foram Aspidodera raillieti, Cruzia tentaculata, Physaloptera mirandai e Viannaia conspicua (Nematoda). Estas espécies também foram as únicas dominantes na comunidade componente. Os hospedeiros machos tiveram maior prevalência de $P$. mirandai e maior abundância de $V$. conspicua. Foi observada uma relação significativa entre o tamanho do corpo do hospedeiro e a abundância de helmintos em hospedeiros machos e fêmeas, e entre o tamanho do corpo do hospedeiro e a riqueza de espécies de helmintos em fêmeas. Este foi o primeiro estudo a analisar a helmintofauna e a estrutura da comunidade de helmintos de M. myosuros. E também foi o primeiro relato da ocorrência de $A$. raillieti e Didelphonema longispiculata em M. myosuros.
\end{abstract}

Palavras-chave: Mata Atlântica, Brasil, Nematoda, ecologia de parasitos, parasitismo.

Received March 12, 2020. Accepted June 26, 2020

*Corresponding author: Rosana Gentile. E-mail: rgentile@ioc.fiocruz.br 


\section{Introduction}

Parasitism plays a key role in the ecosystems because parasites can interfere in processes such as competition, migration, speciation and host reproduction, and can also affect biodiversity (Combes, 2001; Hudson, 2005). Moreover, biotic factors (such as the host gender, age, home range and species richness) and abiotic factors (such as seasonality) may alter the spatial and temporal distribution of a parasite species, thus influencing their abundance and prevalence rates (Combes, 2001).

In Brazil, 62 species of marsupials have been registered (Faria et al., 2019), but their helminth parasites are scarcely known. Most of the studies have consisted of reports on helminth species records (Gomes et al., 2003; Thatcher, 2006; Cardia et al., 2016) and taxonomic descriptions (Torres et al., 2007; Adnet et al., 2009; Araújo, 2011; Chagas-Moutinho et al., 2007; Chero et al., 2017). In addition, only a few studies have been conducted on the helminth community structure of Neotropical marsupials (Quintão e Silva \& Costa, 1999; Antunes, 2005; Jiménez et al., 2011; Zabott et al., 2017; Costa-Neto et al., 2019; Ramírez-Cañas et al., 2019).

The brown four-eyed opossum Metachirus myosuros (Temminck, 1824) (Didelphimorphia, Didelphidae) is a strictly terrestrial marsupial species (Cunha \& Vieira, 2002; Crouzeilles et al., 2010). This species has wide distribution in South America, extending from Honduras, in Central America, to northeastern Argentina (Brown, 2004). In Brazil, M. myosuros occurs in the Amazon, Atlantic Forest, Pantanal and Cerrado biomes (Melo \& Sponchiado, 2012).

Metachirus myosuros may act as a wild reservoir for parasites and may contribute to the transmission of certain zoonoses. It has been reported to be naturally infected by Trypanosoma cruzi Chagas, 1909, the etiological agent of Chagas disease (Marcili et al., 2009), and by Leishmania amazonensis Lainson \& Shaw, 1972, the etiological agent of American cutaneous leishmaniasis (Basano \& Camargo, 2004) in Brazil.

In relation to helminths, all studies published on this host have been reports of species occurrence or species descriptions (Travassos, 1913; Travassos, 1920; Travassos, 1922; Freitas, 1937; Lent \& Freitas, 1937; Proença, 1937; Sarmiento, 1954; Vicente, 1966; Travassos et al., 1969; Grisi \& Castro, 1974; Gomes, 1979a, b; Noronha et al., 2002; Thatcher, 2006; Tantaleán et al., 2010; Barros, 2015; Lopes-Torres et al., 2019). No studies on the helminth fauna or its community structure in this marsupial have so far been published. The aims of the present study were to describe the species composition and analyze the helminth community structure of $M$. myosuros at infracommunity level (within an individual host) and component community level (set of the infracommunities of a given host population), in preserved areas of the Atlantic Forest in Igrapiúna, southern Bahia, Brazil. We also tested whether host gender and age were determinant factors for parasitism in this marsupial.

\section{Materials and Methods}

\section{Study area}

This study formed part of a comprehensive survey project on the biodiversity of the Atlantic Forest fauna and its parasites. It was conducted in preserved areas of the Pratigi Environmental Protection Area $\left(13^{\circ} 51^{\prime} \mathrm{S} ; 3^{\circ} 16^{\prime} \mathrm{W}\right)$ in the municipality of Igrapiúna, southern Bahia. The landscape of this area is formed by valleys and plains within the landholding of the Juliana Valley United Farms (Fazendas Reunidas Vale do Juliana). This comprises a set of agroforestry systems (including areas of rubber, cocoa, clove and peach palm production) and areas of dense ombrophilous forest that form patches linked by ecological corridors (OCT, 2019). The climate of this region is classified as wet equatorial (Af), according to the Köppen climate classification. The type Af is characterized by high temperatures, with high humidity and few seasonal variations, without any dry season (Alvares et al., 2013).

\section{Sampling methods}

The marsupials were collected using Tomahawk ${ }^{\circledR}$ live traps (16 $\times 5 \times 5$ inches), which were placed on the ground along six transects of 15 points. Captures were carried out during ten consecutive nights in August 2014 and again in March 2015. All the traps were baited with a mixture of peanut butter, banana, oatmeal and bacon.

The animals were identified by external morphology, weighed, measured, had their sex registered, and euthanised for helminth recovery. The animals were euthanised as follows. The animals were anesthetised with ketamine hydrochloride $(100 \mathrm{mg} / \mathrm{mL})$ associated with xylazine hydrochloride $(20 \mathrm{mg} / \mathrm{mL})$ in the 
proportion 1:1 with $0.1 \mathrm{~mL} / 100 \mathrm{~g}$ dose. When the animal was completely anesthetised, $19.1 \%$ potassium chloride was applied intracardiac, using a $2 \mathrm{~mL} / \mathrm{kg}$ body weight dose. All animals were preserved by taxidermy and deposited as voucher specimens in the Mammal Collection "Alexandre Rodrigues Ferreira" of the Santa Cruz State University (CMARF-UESC). The presence of helminths was investigated in the trachea, lungs, esophagus, heart, kidneys, liver, pancreas, spleen, small intestine, large intestine, cecum, mesenteric veins, reproductive apparatus and body cavities.

The helminths recovered were washed in physiological saline solution $(0.85 \% \mathrm{NaCl})$. Nematodes were fixed in AFA solution (93 parts 70\% ethanol, 5 parts $0.4 \%$ formalin and 2 parts $100 \%$ acetic acid) and were heated to $65^{\circ} \mathrm{C}$. The flatworms of the classes Trematoda and Cestoda were compressed in cold AFA. The specimens of acanthocephalans were kept in distilled water, fixed and compressed in cold AFA for protraction of the proboscis, as described by Amato et al. (1991). The nematodes were cleared with lactophenol and were placed between a slide and coverslip for identification under an optical microscope. The trematodes, cestodes and acanthocephalans were stained using Langeron's carmine, differentiated with $0.5 \%$ hydrochloric acid, dehydrated in an increasing alcohol series, cleared in methyl salicylate and mounted in Canada balsam as permanent preparations (Amato et al., 1991).

Specimens were counted using a stereoscopic microscope and were identified under an optical microscope (Zeiss Axio Scope A1) that was coupled to an Axio Cam MRc digital camera for photomicrography. The species were identified using morphological characteristics, as described by Vicente et al. (1997) and Anderson et al. (2009) for Nematoda; Travassos et al. (1969) for Trematoda; and Gomes (1979b) for Cestoda and Acanthocephala and other species descriptions. Voucher specimens were deposited at the Helminthological Collection of the Oswaldo Cruz Institute (Appendix 1).

The animals were captured under authorization from the Brazilian Government's Chico Mendes Institute for Biodiversity and Conservation (ICMBio; license number 17131-4) and from the Ethics Committee for Animal Use (CEUA) of the Oswaldo Cruz Foundation (license number LW-39/14) in collaboration with the Federal University of Paraíba (UFPB), Federal University of Rio de Janeiro (UFRJ) and State University of Santa Cruz (UESC). Biosecurity techniques and personal safety equipment were used during all procedures involving animal handling and biological sampling (Lemos \& D'Andrea, 2014).

\section{Data analysis}

The abundance, intensity and prevalence of each helminth species were calculated according to Bush et al. (1997). The mean abundance was calculated by dividing the total number of parasites by the total number of hosts. For the mean intensity, the total number of parasites was divided by the number of infected hosts. Prevalence was calculated by dividing the number of hosts infected by the total number of hosts and multiplied by 100 . The sex ratio of the most abundant helminth species was tested if it differed from $1: 1$, using the $\chi^{2}$ contingency test.

The mean species richness was calculated as the mean number of helminth species for each infracommunity, while the species richness was the total number of helminth species recovered. The estimated species richness was calculated using the nonparametric Jackknife 2 estimator (Magurram, 2004).

The parameters of the most prevalent and abundant species were compared in relation to host gender. The abundances were compared using the nonparametric Mann-Whitney test. The prevalences were compared using the $\chi^{2}$ contingency test.

We also investigated the influence of host age, based on host body size, on the total abundance and species richness for each infracommunity, using linear regression separately for each host gender. Significance of the regression coefficient (beta) was evaluated using t test. Since body size is related to age, we hypothesized that older hosts would be more parasitized than younger ones.

The importance value, l, was calculated for each of the helminth species as described by Thul et al. (1985). From this, each species was then classified in the community as dominant $(I \geq 1.0)$, co-dominant $(0.01 \leq I<1.0)$, subordinate $(I<0.01)$ or an unsuccessful pioneer $(I=0)$.

The analyses were done in accordance with Zar (1996), using the Past software, version 3.21 (Hammer et al., 2001). The data were tested for normal distribution using the Shapiro-Wilk test. In all analyses, the significant level was taken to be $5 \%$. 


\section{Results}

A total of 19 specimens of $M$. myosuros were captured ( 8 females and 11 males). Ninety-five percent of the hosts (18) were infected by at least one helminth species. A total of 3,299 helminths were recovered. The overall helminth species richness was 10 and the estimated species richness was 14.66 . The mean helminth species richness was 4 , and this ranged from zero to seven.

Seven nematode species were identified: Aspidodera raillieti Travassos, 1913 (Ascaridida, Aspidoderidae) and Cruzia tentaculata (Rudolphi, 1819) Travassos, 1917 (Ascaridida, Kathlaniidae) in the large intestine; Physaloptera mirandai Lent \& Freitas, 1937 (Spirurida, Physalopteridae) in the stomach; and Didelphonema longispiculata (Hill, 1939) Wolfgang, 1953 (Spirurida, Spirocercidae), Viannaia conspicua Travassos, 1914 (Rhabditida, Viannaiidae), Viannaia pusilla Travassos, 1914 (Rhabditida, Viannaiidae) and three female specimens in the superfamily Trichostrongyloidea in the small intestine. These last specimens could not be identified at species level due to the absence of males and to the state of the material, which prevented visualization of internal structures. Two species of Platyhelminthes were identified: the digenean Rhopalias coronatus (Rudolphi, 1819) Stiles \& Hassall, 1898 (Plagiorchiida, Rhopaliidae) and the cestode Mathevotaenia bivittata (Janicki, 1904) Akhumian, 1946 (Cyclophyllidea, Anoplocephalidae), both in the small intestine. One species of Acanthocephala was observed: Oligacanthorhynchus microcephalus (Rudolphi, 1819) Schmidt, 1972 (Archiacanthocephala, Oligacanthorhynchidae), also in the small intestine.

We recovered a total of 124 adult helminths of P. mirandai, 2,371 of C. tentaculata, 128 of A. raillieti, 464 of $V$. conspicua and 98 of $V$. pusilla. The nematodes $C$. tentaculata and $V$. conspicua were the most abundant species (Table 1). The prevalence was higher for the nematodes A. raillieti, C. tentaculata, $P$. mirandai and $V$. conspicua (Table 1). Viannaia pusilla, $R$. coronatus and the Trichostrongyloidea specimens were found only in male hosts (Table 1). The nematode $D$. longispiculata was found in a single male host in 2014 (Table 1).

The sex ratios of $A$. raillieti and $P$. mirandai did not significantly differ from 1:1 (Table 2). Cruzia tentaculata, $V$. conspicua and $V$. pusilla had significantly more females than males (Table 2 ).

The influence of host gender on the parameters found was investigated for the species A. raillieti, C. tentaculata, $P$. mirandai and $V$. conspicua. The nematodes $P$. mirandai and $V$. conspicua showed a statistically significant difference in prevalence in relation to host gender, with higher values for male hosts (Table 3 ). The abundance of $V$. conspicua was significantly higher in male hosts (Table 4).

A significant relationship was observed between helminth abundance and host body size for both sexes (males: regression coefficient (beta - slope) $=0.657, \mathrm{t}=2.617, p=0.028, \mathrm{n}=11$; females: beta $=0.707, \mathrm{t}=2.451$, $p=0.050, \mathrm{n}=8$ ). However, for helminth species richness, the relationship with host body size was clear only for females (males: beta $=-0.189, \mathrm{t}=-0.189, p=0.578, \mathrm{n}=11$; females: beta $=0.797, \mathrm{t}=3.237, p=0.018, \mathrm{n}=8$ ).

The nematodes were dominant in the component community of $M$. myosuros with the exception of $D$. longispiculata and $V$. pusilla, which were co-dominant and Trichostrongyloidea specimens, which were subordinate (Table 5). The cestodes were co-dominant and the trematodes were subordinate (Table 5). The acanthocephalans were co-dominant (Table 5).

\section{Discussion}

Metachirus myosuros is recorded as a new host for the nematodes $A$. raillieti and $D$. longispiculata. This study also provides the first record of the species A. raillieti, C. tentaculata, D. Iongispiculata, V. conspicua, V. pusilla, M. bivittata, $R$. coronatus and $O$. microcephalus in the state of Bahia, Brazil. Previous studies on helminths in M. myosuros were based on new taxonomic descriptions and new records of species occurrence (Table 6) without reports of abundance or prevalence indices. Twenty-four helminth species had previously been described infecting this marsupial (Table 6), including species in three phyla. Among the nine helminth species identified in the present study, seven had previously been reported infecting $M$. myosuros.

Before the present study, A. raillieti had been reported parasitizing Didelphis aurita (Wied-Neuwied, 1826), Caluromys lanatus (Olfers, 1818), Didelphis marsupialis Linnaeus, 1758, Chironectes minimus (Zimmermann, 1780), Philander opossum (Linnaeus, 1758) and Nectomys squamipes (Brants, 1827) in Brazil (Vicente et al., 1997). Quintão e Silva \& Costa (1999) found A. raillieti in Didelphis albiventris Lund, 1840, also in Brazil. The only species of this genus previously found parasitizing M. myosuros was Aspidodera subulata (Molin, 1860) Railliet \& Henry, 1912, which was 


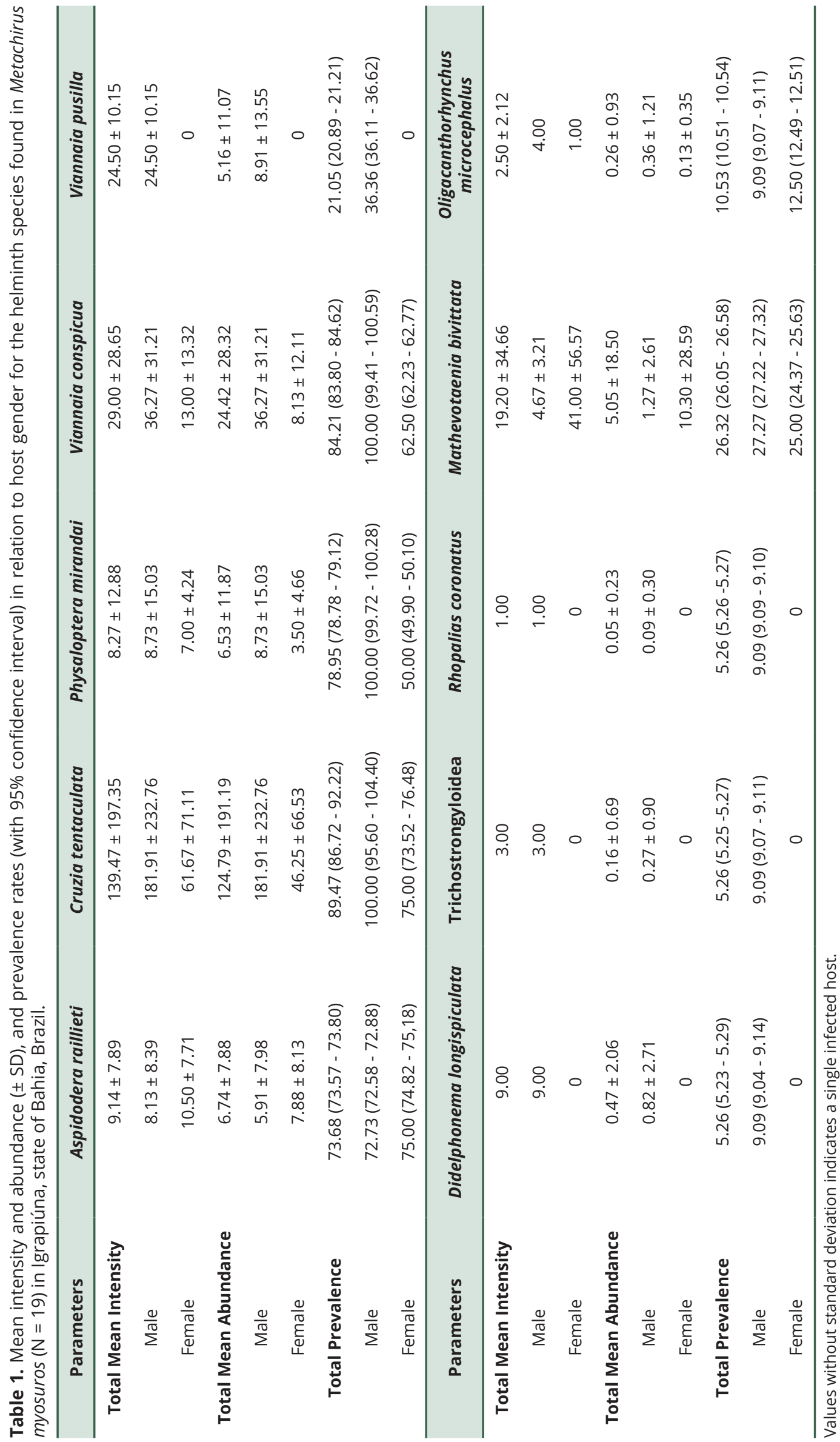


Table 2. Chi-square and probability values for the sex ratio of the most abundant helminth species found in Metachirus myosuros in Igrapiúna, Bahia, Brazil.

\begin{tabular}{clc}
\hline Species & $\boldsymbol{\chi}^{2}$ & $\boldsymbol{p}$ \\
\hline Aspidodera raillieti & 0.21 & 0.17 \\
Cruzia tentaculata & 0.0001 & $1.32^{-13 *}$ \\
Physaloptera mirandai & 0.25 & 0.20 \\
Viannaia conspicua & 0.0001 & $4.63^{-06 *}$ \\
Viannaia pusilla & 0.0024 & $0.001^{*}$ \\
\hline
\end{tabular}

* Significant values.

Table 3. Chi-square and probability values for comparison of prevalences between host genders, for the most abundant helminth species in Metachirus myosuros in Igrapiúna, Bahia, Brazil.

\begin{tabular}{ccc}
\hline Species & $\chi^{2}$ & $p$ \\
\hline Aspidodera raillieti & 1 & 0.91 \\
Cruzia tentaculata & 0.17 & 0.08 \\
Physaloptera mirandai & 0.01 & $0.008^{*}$ \\
Viannaia conspicua & 0.06 & $0.03^{*}$ \\
\hline
\end{tabular}

\footnotetext{
* Significant values.
}

Table 4. Results from the Mann-Whitney $U$ test for comparison of helminth abundances between host genders, for Metachirus myosuros in Igrapiúna, Bahia, Brazil.

\begin{tabular}{ccc}
\hline Species & $\boldsymbol{U}$ & $\boldsymbol{p}$ \\
\hline Aspidodera raillieti & 38.5 & 0.67 \\
Cruzia tentaculata & 24 & 0.11 \\
Physaloptera mirandai & 28 & 0.19 \\
Viannaia conspicua & 13 & $0.01^{*}$ \\
\hline
\end{tabular}

\footnotetext{
* Significant values.
}

Table 5. Importance indices for each helminth species found in Metachirus myosuros in Igrapiúna, state of Bahia, Brazil.

\begin{tabular}{ccc}
\hline Helminths species & Importance Indices & Classification \\
Aspidodera raillieti & 3.428 & Dominant \\
Cruzia tentaculata & 77.101 & Dominant \\
Didelphonema longispiculata & 0.017 & Co-dominant \\
Physaloptera mirandai & 3.558 & Dominant \\
Viannaia conspicua & 14.201 & Co-dominant \\
Viannaia pusilla & 0.750 & Subordinate \\
Trichostrongyloidea & 0.006 & Co-dominant \\
Mathevotaenia bivittata & 0.918 & Subordinate \\
Rhopalias coronatus & 0.002 & Co-dominant
\end{tabular}


Table 6. List of records of helminth species found in Metachirus myosuros, with locality, infection site and data sources.

\begin{tabular}{|c|c|c|c|}
\hline Helminth & Locality & Site & References \\
\hline \multicolumn{4}{|l|}{ Nematoda } \\
\hline Aspidodera sp. & Peru & Large intestine & Tantaleán et al. (2010) \\
\hline Aspidodera raillieti & Igrapiúna, BA, Brazil & Large intestine & Present study \\
\hline \multirow[t]{4}{*}{ Aspidodera subulata } & Brazil & Large intestine & Travassos (1913) \\
\hline & Brazil & & Proença (1937) \\
\hline & Brazil & & Vicente (1966) \\
\hline & Brazil & & Thatcher (2006) \\
\hline Capillaria sp. & Angra dos Reis, RJ, Brazil & Small intestine & Noronha et al. (2002) \\
\hline \multirow[t]{4}{*}{ Cruzia tentaculata } & South America & Large intestine & Travassos (1922) \\
\hline & Brazil & & Thatcher (2006) \\
\hline & Peru & & Tantaleán et al. (2010) \\
\hline & Igrapiúna, BA, Brazil & & Present study \\
\hline Didelphonema longispiculata & Igrapiúna, BA, Brazil & Small intestine & Present study \\
\hline Dracunculus sp. & Bom Retiro, RJ, Brazil & Under the skin & Noronha et al. (2002) \\
\hline \multirow[t]{5}{*}{ Physaloptera mirandai } & Angra dos Reis, RJ, Brazil & Stomach & $\begin{array}{l}\text { Lent \& Freitas (1937); } \\
\text { Tantaleán et al. (2010); } \\
\text { Barros (2015) }\end{array}$ \\
\hline & Peru & & Lopes-Torres et al. (2019) \\
\hline & Acre and Bahia, Brazil & & Present study \\
\hline & Espírito Santo, Brazil & & \\
\hline & Igrapiúna, BA, Brazil & & \\
\hline Physaloptera sp. & Peru & Stomach & Tantaleán et al. (2010) \\
\hline \multirow[t]{2}{*}{ Travassostrongylus orloffi } & Angra dos Reis, RJ, Brazil & Small intestine & Freitas (1937) \\
\hline & Brazil & & Thatcher (2006) \\
\hline Travassostrongylus quatuor & Angra dos Reis, RJ, Brazil & Small intestine & Freitas (1937) \\
\hline Travassostrongylus quintus & Angra dos Reis, RJ, Brazil & Small intestine & Freitas (1937) \\
\hline Travassostrongylus sextus & Angra dos Reis, RJ, Brazil & Small intestine & Freitas (1937) \\
\hline \multirow[t]{2}{*}{ Travassostrongylus tertius } & Angra dos Reis, RJ, Brazil & Small intestine & Freitas (1937) \\
\hline & Rio de Janeiro, Brazil & & Thatcher (2006) \\
\hline \multirow[t]{2}{*}{ Turgida turgida } & Brazil & Stomach & Travassos (1920) \\
\hline & Brazil & & Travassos et al. (1969) \\
\hline \multirow[t]{2}{*}{ Viannaia conspicua } & Angra dos Reis, RJ, Brazil & Small intestine & Freitas (1937) \\
\hline & Igrapiúna, BA, Brazil & & Present study \\
\hline \multirow[t]{3}{*}{ Viannaia pusilla } & $\begin{array}{c}\text { Angra dos Reis, RJ, Brazil Rio de } \\
\text { Janeiro, Brazil }\end{array}$ & Small intestine & Freitas (1937) \\
\hline & Igrapiúna, BA, Brazil & & Thatcher (2006) \\
\hline & & & Present study \\
\hline
\end{tabular}


Table 6. Continued...

\begin{tabular}{|c|c|c|c|}
\hline Helminth & Locality & Site & References \\
\hline Viannaia sp. & $\begin{array}{c}\text { Angra dos Reis, RJ, Brazil } \\
\text { Peru }\end{array}$ & Small intestine & $\begin{array}{l}\text { Noronha et al. (2002) } \\
\text { Tantaleán et al. (2010) }\end{array}$ \\
\hline \multicolumn{4}{|l|}{ Platyhelminthes } \\
\hline \multicolumn{4}{|l|}{ Class Trematoda } \\
\hline Duboisiella proloba & Huánuco, Peru & Caecum & Chero et al. (2017) \\
\hline & & intestine & \\
\hline \multirow[t]{2}{*}{ Lyperosomum silvai } & $\begin{array}{c}\text { Santa Maria Madalena, RJ, } \\
\text { Brazil }\end{array}$ & Bile ducts & Grisi \& Castro (1974) \\
\hline & & & Gomes (1979a) \\
\hline Plagiorchis didelphidis & Huánuco, Peru & Caecum, small intestine & Chero et al. (2017) \\
\hline \multirow[t]{2}{*}{ Podospathalium pedatum } & Brazil & Intestine & $\begin{array}{c}\text { Travassos et al. (1969), } \\
\text { Thatcher (2006) }\end{array}$ \\
\hline & Brazil & & \\
\hline Rhopalias baculifer & Huánuco, Peru & Small intestine & Chero et al. (2017) \\
\hline \multirow[t]{4}{*}{ Rhopalias coronatus } & Brazil & Small intestine & Travassos et al. (1969) \\
\hline & Angra dos Reis, RJ, Brazil & & Gomes (1979a) \\
\hline & Huánuco, Peru & & Chero et al. (2017) \\
\hline & Igrapiúna, BA, Brazil & & Present study \\
\hline Rhopalias horridus & Brazil & Intestine & Travassos et al. (1969) \\
\hline \multicolumn{4}{|l|}{ Class Cestoda } \\
\hline Linstowia jheringi & Brazil & Small intestine & Thatcher (2006) \\
\hline \multirow[t]{3}{*}{ Mathevotaenia bivittata } & Angra dos Reis, RJ, Brazil & Small intestine & Gomes (1979b) \\
\hline & Brazil & & Thatcher (2006) \\
\hline & Igrapiúna, BA, Brazil & & Present study \\
\hline Pritchardia boliviensis & Bolivia & Small intestine & Gardner et al. (2013) \\
\hline \multicolumn{4}{|l|}{ Acanthocephala } \\
\hline \multirow[t]{3}{*}{ Gigantorhynchus ortizi } & La Merced, Peru & Intestine & Sarmiento (1954) \\
\hline & Peru, Colombia and Brazil & & Thatcher (2006) \\
\hline & Peru & & Tantaleán et al. (2010) \\
\hline Oligacanthorhynchus microcephalus & $\begin{array}{l}\text { Angra dos Reis, RJ, Brazil } \\
\text { Igrapiúna, BA, Brazil }\end{array}$ & $\begin{array}{c}\text { Small intestine, } \\
\text { subcutaneous tissue and } \\
\text { cysts in peritoneal cavity }\end{array}$ & Gomes (1979b) \\
\hline
\end{tabular}

reported by Travassos (1913), Proença (1937), Vicente (1966) and Thatcher (2006). Didelphonema longispiculata was reported by Wolfgang (1953) in Didelphis marsupialis in North America and the Lesser Antilles.

Cruzia tentaculata was reported parasitizing M. myosuros by Travassos (1922) and Thatcher (2006) in Brazil and by Tantaleán et al. (2010) in Peru. Viannaia conspicua and V. pusilla were found in this marsupial by Freitas (1937) in Angra dos Reis, state of Rio de Janeiro, Brazil, and the latter was also reported by Thatcher (2006) in Brazil. Lent \& Freitas (1937) reported P. mirandai in M. myosuros in Angra dos Reis, Brazil; Barros (2015) found this species in the states of Acre and Bahia, Lopes-Torres et al. (2019) in the state of Espírito Santo, Brazil, and Tantaleán et al. (2010) in Peru.

From the phylum Platyhelminthes, the trematode $R$. coronatus was reported in M. myosuros by Travassos et al. (1969) in Brazil, Gomes (1979a) in Angra dos Reis, Brazil, and Chero et al. (2017) in Huánuco, Peru. The cestode 
M. bivittata was also reported for this marsupial by Gomes (1979b) in Angra dos Reis, Brazil. The same studies also reported O. microcephalus in M. myosuros (Gomes, 1979b).

Cruzia tentaculata, V. conspicua and V. pusilla were found in the present study to have sex ratios biased toward females, which suggests that this may be an ecological reproduction strategy in these species. A larger number of females leads to higher numbers of eggs released, thus increasing the chances of host infection. This pattern is most common in species with a polygamous mating system (Poulin, 2007), but there is no information in the literature about the mating system of these species. Nonetheless, similar results were found by Antunes (2005), Castro et al. (2017) and Costa-Neto et al. (2019) for C. tentaculata.

In some studies, it was observed that male marsupials of other species presented behavior of a more exploratory nature: these included Marmosa (Micoureus) demerarae (Thomas, 1905) (Morais-Júnior \& Chiarello, 2005) and Didelphis aurita (Wied-Neuwied, 1826) (Loretto \& Vieira, 2005). Such behavior may increase the chances of parasitic infection. In addition, testosterone can decrease host immunity and this can also be correlated with higher occurrence of parasites in male hosts (Combes, 2001). This may explain the greater abundance of $V$. conspicua and higher prevalence of $P$. mirandai and $V$. conspicua in male hosts, as well as the occurrence of $V$. pusilla, R. coronatus, $D$. longispiculata and Trichostrongyloidea specimens only in male hosts.

The helminth abundance increased with increasing host body size, suggesting that older animals were infected with more parasites than younger ones. It can be expected that larger hosts may have a larger number of parasites as well as more parasite species (Guégan et al., 1992; Morand \& Poulin, 1998; Combes, 2001). For helminth species richness, this relationship could be observed only for females.

The fact that the overall estimated richness (14.66) was higher than the observed results (10) may indicate that more species could be present in the helminth fauna if the sample size were to be increased, and that rare species may also be present in the helminth community. The presence of only two subordinate species among the ten species observed corroborates this idea. The dominance of the nematodes A. raillieti, C. tentaculata, P. mirandai and $V$. conspicua in the component community of M. myosuros may indicate that these species have characteristics that make them more tolerant to the external environment and to the specificities of the host-parasite interaction, in relation to the other helminths found. Except for $P$. mirandai, the other three species have been reported to be transmitted through egg ingestion (Jiménez et al., 2011; Taylor et al., 2017), which can facilitate transmission of the parasite. Other studies have also reported that $A$. raillieti and $C$. tentaculata are dominant species in other marsupial hosts. Quintão e Silva \& Costa (1999), in the state of Minas Gerais, Brazil, and Antunes (2005) in the state of Rio Grande do Sul, Brazil, found high prevalence and high mean intensity rates for $C$. tentaculata and $A$. raillieti in $D$. albiventris. Jiménez et al. (2011) found $A$. raillieti to be a dominant species in component communities in P. opossum and D. marsupialis in French Guiana. Costa-Neto et al. (2019) found C. tentaculata and A. raillieti to be the most dominant species in D. aurita in three areas of the Atlantic Forest in Brazil. Ramírez-Cañas et al. (2019) found a high prevalence of $C$. tentaculata in $P$. opossum in Mexico.

This was a novel study on the helminth community structure of the marsupial M. myosuros, albeit preliminary. This study not only contributes new records of helminth species and helminth parasitological parameters, but also enables better understanding of the parasite community and parasitism in small mammals.

\section{Acknowledgments}

We would like to thank the staff and students of Laboratório de Biologia e Parasitologia de Mamíferos Silvestres Reservatórios from Fundação Oswaldo Cruz and to Dr. Martin Alvarez and his students from the Mammal Section at the Universidade Estadual de Santa Cruz who helped in the field work. We also thank Dr. M. Alvarez for the ICMBIO license and field work organization; Fazendas Reunidas Vale do Juliana S/A for the help in food and lodging; Dr. R. Cerqueira and Dr. P. C. Estrela for the coordination of the general project PPBio Rede BioM.A.; Dr. A.P.G. Nascimento for the acanthocephalan identification. This project was financially supported by Conselho Nacional de Desenvolvimento Científico e Tecnológico - CNPq - PPBio Rede BioM.A (457524/2012-0), Instituto Oswaldo Cruz (IOC - FIOCRUZ) and Programa de Pós-Graduação em Biodiversidade e Saúde (IOC-FIOCRUZ). BSC received grants from the Programa de Estágio Curricular at Fundação Oswaldo Cruz. SFCN received grants from Coordenação de Aperfeiçoamento de Pessoal de Nível Superior (CAPES) - Brasil - Finance code 001. RG received researcher grants form CNPq (304355/2018-6). 


\section{References}

Adnet FAO, Anjos DHS, Menezes-Oliveira A, Lanfredi RM. Further description of Cruzia tentaculata (Rudolphi, 1819) Travassos, 1917 (Nematoda: Cruzidae) by light and scanning electron microscopy. Parasitol Res 2009; 104(5): 1207-1211. http://dx.doi. org/10.1007/s00436-008-1316-6. PMid:19130086.

Alvares CA, Stape JL, Sentelhas PC, Gonçalves JL, Sparovek G. Köppen's climate classification map for Brazil. Meteorol Z (Berl) 2013; 22(6): 711-728. http://dx.doi.org/10.1127/0941-2948/2013/0507.

Amato JF, Walter AB, Amato SB. Protocolo para Laboratório: Coleta e Processamento de Parasitas do Pescado. 1st ed. Rio de Janeiro: Imprensa Universitária; 1991.

Anderson RC, Chaubaud AG, Willmott S. Keys to the nematode parasites of vertebrates: Archival volume. Wallingford, UK: CABI Publishing; 2009. http://dx.doi.org/10.1079/9781845935726.0000.

Antunes GM. Diversidade e potencial zoonótico de parasitos de Didelphis albiventris Lund, 1841 (Marsupialia: Didelphidae) [tese]. Porto Alegre: Universidade Federal do Rio Grande do Sul; 2005.

Araújo LRF. Descrição taxonômica de Cruzia sp. nov. e Aspidodera sp. nov. (Nematoda, Ascaridida), parasitas de intestino grosso de Philander opossum Linnaeus, 1758, marsupial de Carajás-Pará, Brasil [dissertação]. Belém: Universidade Federal do Pará; 2011.

Barros JSL. Taxonomia morfológica e filogenia molecular de Physaloptera (Nematoda: spirurida) [tese]. Rio de Janeiro: Instituto Oswaldo Cruz; 2015.

Basano SA, Camargo LMA. Leishmaniose tegumentar americana: histórico, epidemiologia e perspectivas de controle. Rev Bras Epidemiol 2004; 7(3): 328-337. http://dx.doi.org/10.1590/S1415-790X2004000300010.

Brown BE. Atlas of New World Marsupials. Fieldiana: Zoology; 2004. (New Series). http://dx.doi.org/10.5962/bhl.title.3410.

Bush AO, Lafferty KD, Lotz JM, Shostak AW. Parasitology meets ecology on its own terms: margolis et al. revisited. J Parasitol 1997; 83(4): 575-583. http://dx.doi.org/10.2307/3284227. PMid:9267395.

Cardia DFF, Camossi LG, Fornazari F, Babboni SD, Teixeira CR, Bresciani KD. First report of Strongyloides sp. (Nematoda, Strongyloididae) in Lutreolina crassicaudata (Didelphimorphia: didelphidae). Braz J Biol 2016; 76(4): 884-887. http://dx.doi. org/10.1590/1519-6984.03315. PMid:27143055.

Castro RG, Costa-Neto SF, Maldonado AJr, Gentile R. Ecological aspects of nematode parasites of Didelphis aurita (Didelphimorphia, Didelphidae) in urban-sylvatic habitats in Rio de Janeiro, Brazil. Oecol Aust 2017; 21(1): 54-61. http://dx.doi.org/10.4257/ oeco.2017.2101.06.

Chagas-Moutinho VA, Oliveira-Menezes A, Cárdenas MQ, Lanfredi RM. Further description of Aspidodera raillieti (Nematoda: Aspidoderidae) from Didelphis marsupialis (Mammalia: Didelphidae) by light and scanning electron microscopy. Parasitol Res 2007; 101(5): 1331-1336. http://dx.doi.org/10.1007/s00436-007-0641-5. PMid:17622560.

Chero JD, Sáez G, Mendoza-Vidaurre C, lannacone J, Cruces CL. Helminths of the common opossum Didelphis marsupialis (Didelphimorphia: Didelphidae), with a checklist of helminths parasitizing marsupials from Peru. Rev Mex Biodivers 2017; 88(3): 560-571. http://dx.doi.org/10.1016/j.rmb.2017.07.004.

Combes C. Parasitism: The ecology and evolution of intimate interactions. Chicago and London: University of Chicago Press; 2001.

Costa-Neto SF, Cardoso TS, Boullosa RG, Maldonado A Jr, Gentile R. Metacommunity structure of the helminths of the blackeared opossum Didelphis aurita in peri-urban, sylvatic and rural environments in south-eastern Brazil. J Helminthol 2019; 93(6): 720-731. http://dx.doi.org/10.1017/S0022149X18000780. PMid:30220264.

Crouzeilles R, Barros CS, Fernandez FA. Philander frenatus e Metachirus nudicaudatus: competição ou necessidades ecológicas diferentes na Floresta Atlântica? Mastozool Neotrop 2010; 17(1): 135-140.

Cunha A, Vieira MV. Support diameter, incline, and vertical movements of four didelphid marsupials in the Atlantic Forest of Brazil. J Zool (Lond) 2002; 258(4): 419-426. http://dx.doi.org/10.1017/S0952836902001565.

Faria MB, Lanes RO, Bonvicino CR. Marsupiais do Brasil: guia de identificação com base em caracteres morfológicos externos e cranianos. 1st ed. São Caetano do Sul: Amélie Editorial; 2019.

Freitas JFT. Sobre algumas especies do genero Travassostrongylus Orloff, 1933: (Nematoda: Trichostrongylidae). Mem Inst Oswaldo Cruz 1937; 32(2): 217-220. http://dx.doi.org/10.1590/S0074-02761937000200004.

Gardner SL, Jiménez FA, Campbell ML. Pritchardia boliviensis n. gen., n. sp. (Anoplocephalidae: Linstowinae), a tapeworm from opossums (Didelphidae) in the Yungas and lowlands of Bolivia and Atlantic Forest of Paraguay. Occas Pap Tex Tech Univ 2013; 319: 1-8. http://dx.doi.org/10.5281/zenodo.1035204.

Gomes DC, Cruz RPD, Vicente J], Pinto RM. Nematode parasites of marsupials and small rodents from the Brazilian Atlantic Forest in the State of Rio de Janeiro, Brazil. Rev Bras Zool 2003; 20(4): 699-707. http://dx.doi.org/10.1590/S0101-81752003000400024. 
Gomes DC. Contribuição ao conhecimento dos helmintos parasitos de marsupiais no Brasil, da Coleção Helmintológica do Instituto Oswaldo Cruz - Trematoda. Atas Soc Biol Rio de Janeiro 1979a; 20(00): 33-43.

Gomes DC. Contribuição ao conhecimento dos helmintos parasitos de marsupiais no Brasil, da Coleção Helmintológica do Instituto Oswaldo Cruz (Cestoda, Archiacanthocephala e Linguatulida). Rev Iber Parasitol 1979b; 39(00): 587-599.

Grisi L, Castro PT. Sobre uma nova espécie de Lyperosomum Loss, 1899 parasita de marsupiais (Trematoda, Dicrocoelidae). Rev Bras Biol 1974; 34(1): 119-122. PMid:4463417.

Guégan JF, Lambert A, Lévêque C, Combes C, Euzet L. Can host body size explain the parasite species richness in tropical freshwater fishes? Oecologia 1992; 90(2): 197-204. http://dx.doi.org/10.1007/BF00317176. PMid:28313714.

Hammer O, Harper DA, Ryan PD. PAST: Paleontological Statistics software package for education and data analysis. Palaeontol Electronica 2001; 4(1): 9.

Hudson P. Parasites, diversity, and the ecosystem. In: Thomas F, Renaud F, Guégan JF, editors. Parasitism and Ecosystems. Nova York: Oxford University Press; 2005. p. 1-12.

Jiménez FA, Catzeflis F, Gardner SL. Structure of parasite component communities of Didelphid marsupials: insights from a comparative study.J Parasitol 2011; 97(5): 779-787. http://dx.doi.org/10.1645/GE-2711.1. PMid:21506798.

Lemos ER, D'Andrea PS. Trabalho de campo com animais: procedimentos, riscos e biossegurança. Rio de Janeiro: Editora Fiocruz; 2014.

Lent H, Freitas JF. Nova Physaloptera parasita de marsupial: (Nematoda: Spiruroidea). Mem Inst Oswaldo Cruz 1937; 32(2): 221223. http://dx.doi.org/10.1590/S0074-02761937000200005.

Lopes-Torres EJ, Girard-Dias W, Mello WN, Simões RO, Pinto IS, Maldonado A Jr, et al. Taxonomy of Physaloptera mirandai (Nematoda: Physalopteroidea) based in three-dimensional microscopy and phylogenetic positioning. Acta Trop 2019; 195: 115126. http://dx.doi.org/10.1016/j.actatropica.2019.04.002. PMid:31039334.

Loretto D, Vieira MV. The effects of reproductive and climatic seasons on movements in the black-eared opossum (Didelphis aurita Wied-Neuwied, 1826). J Mammal 2005; 86(2): 287-293. http://dx.doi.org/10.1644/BEH-117.1.

Magurram AE. Measuring biological diversity. Oxford, U.K: Blackwell Publishing; 2004.

Marcili A, Lima L, Valente VC, Valente SA, Batista JS, Junqueira AC, et al. Comparative phylogeography of Trypanosoma cruzi TCIlc: new hosts, association with terrestrial ecotopes, and spatial clustering. Infect Genet Evol 2009; 9(6): 1265-1274. http://dx.doi. org/10.1016/j.meegid.2009.07.003. PMid:19632356.

Melo GL, Sponchiado J. Distribuição geográfica de marsupiais no Brasil. In: Cáceres NC, editor. Os marsupiais do Brasil: biologia, ecologia e conservação. Campo Grande: Ed. UFMS; 2012. p. 95-112.

Morais-Júnior EA, Chiarello AG. A radio tracking study of home range and movements of the marsupial Micoureus demerarae (Thomas) (Mammalia, Didelphidae) in the Atlantic forest of south-eastern Brazil. Rev Bras Zool 2005; 22(1): 85-91. http://dx.doi. org/10.1590/S0101-81752005000100011.

Morand S, Poulin R. Density, body mass and parasite species richness of terrestrial mammals. Evol Ecol 1998; 12(6): 717-727. http://dx.doi.org/10.1023/A:1006537600093.

Noronha D, Vicente JJ, Pinto RM. A survey of new host records for nematodes from mammals deposited in the Helminthological Collection of the Oswaldo Cruz Institute (CHIOC). Rev Bras Zool 2002; 19(3): 945-949. http://dx.doi.org/10.1590/S010181752002000300032

Organização de Conservação da Terra - OCT. Apa do Pratigi: Apresentação [online]. Ibirapitanga, BA: OCT; 2019 [cited 2019 Aug 6]. Available from: https://www.oct.org.br/apa-do-pratigi/apresentacao/19.

Poulin R. Evolutionary Ecology of Parasites. Princeton, USA: Princeton University Press; 2007.

Proença MC. Revisão do genero Aspidodera Railliet \& Henry, 1912: (Nematoda: Subuluroidea). Mem Inst Oswaldo Cruz 1937; 32(3): 427-438. http://dx.doi.org/10.1590/S0074-02761937000300005.

Quintão e Silva MG, Costa HMA. Helminths of white-bellied opossum from Brazil. J Wildl Dis 1999; 35(2): 371-374. http://dx.doi. org/10.7589/0090-3558-35.2.371. PMid:10231765.

Ramírez-Cañas SA, George-Nascimento M, García-Prieto L, Mata-López R. Helminth community structure of the gray four-eyed opossum Philander opossum (Mammalia: Didelphidae) in the Neotropical Portion of Mexico. J Parasitol 2019; 105(4): 624-629. http://dx.doi.org/10.1645/18-195. PMid:31418650.

Sarmiento L. Gigantorhynchus ortizi n. sp., an acanthocephalan from Metachirus nudicaudatus. J Parasitol 1954; 40(4): 448-452. http://dx.doi.org/10.2307/3273894. PMid:13192545.

Tantaleán M, Díaz M, Sánchez N, Portocarrero H. Endoparásitos de micromamíferos del noroeste de Perú. 1: helmintos de marsupiales. Rev Peru Biol 2010; 17(2): 207-213. http://dx.doi.org/10.15381/rpb.v17i2.29. 
Taylor MA, Coop RL, Wall RL. Parasitologia Veterinária. 4th ed. Rio de Janeiro: Guanabara Koogan; 2017.

Thatcher VE. Os Endoparasitos de Marsupiais Brasileiros. In: Cáceres NC, Monteiro EL Fo, editors. Os Marsupiais do Brasil. 1st ed. Campo Grande: Editora UFMS; 2006. p. 53-68.

Thul JE, Forrester DJ, Abercrombie CL. Ecology of parasitic helminths of wood ducks, Aix sponsa, in the Atlantic flyway. Proc Helminthol Soc Wash 1985; 52(2): 297-310.

Torres EL, Maldonado AJr, Lanfredi RM. Pterygodermatites (Paucipectines) Jägerskiöldi (Nematoda: Rictulariidae) from Gracilinanus agilis and G. microtarsus (Marsupialia: Didelphidae) in Brazilian pantanal and Atlantic forest by light and scanning electron microscopy.J Parasitol 2007; 93(2): 274-280. http://dx.doi.org/10.1645/GE-986R2.1. PMid:17539409.

Travassos L. Sobre as especies brazileiras da subfamilia Heterakinae Railliet \& Henry. Mem Inst Oswaldo Cruz 1913; 5(3): 271 -318. http://dx.doi.org/10.1590/S0074-02761913000300005.

Travassos L. Contribuições para o conhecimento da fauna helmintolojica brasileira - X. Sobre as espécies do genero Turgida. Mem Inst Oswaldo Cruz 1920; 12(1): 73-77. http://dx.doi.org/10.1590/S0074-02761920000100006.

Travassos L. Contribuições para o conhecimento da fauna helmintolojica brasileira - XVI. Cruzia tentaculata (RUD., 1819). Mem Inst Oswaldo Cruz 1922; 14(1): 88-94. http://dx.doi.org/10.1590/S0074-02761922000100004.

Travassos L, Freitas JF, Kohn A. Trematódeos do Brasil. Mem Inst Oswaldo Cruz 1969; 67(1): 1-886. PMid:5397756.

Vicente JJ. Revisão da subfamília Aspidoderinae Skrjabin \& Shikhobalova, 1947 (Nematoda). Mem Inst Oswaldo Cruz 1966; 64(0): 131-161. http://dx.doi.org/10.1590/S0074-02761966000100008.

Vicente J], Rodrigues HO, Gomes DC, Pinto RM. Nematóides do Brasil. Parte V: nematóides de mamíferos. Rev Bras Zool 1997; 14(Suppl 1): 1-452. http://dx.doi.org/10.1590/S0101-81751997000500001.

Wolfgang RW. Studies on the endoparasitic fauna of trinidad mammals: IX. Didelphonema, a new genus of nematode from marsupials. Can J Zoo/ 1953; 31(5): 519-521. http://dx.doi.org/10.1139/z53-035.

Zabott MV, Pinto SB, Viott AM, Gruchouskei L, Bittencourt LHF. Helmintofauna de Didelphis albiventris (Lund, 1841) no município de Palotina, Paraná, Brasil. Arq Ciênc Vet Zool UNIPAR 2017; 20(1): 19-22. http://dx.doi.org/10.25110/arqvet.v20i1.2017.6315.

Zar JH. Biostatistical analysis. 3rd ed. New Jersey: Prentice Hall; 1996. 
Appendix 1. Voucher specimens deposited in the Helminthological Collection of the Oswaldo Cruz Institute (CHIOC).

\begin{tabular}{cc} 
Species & CHIOC numbers \\
\hline Aspidodera raillieti & 38911 \\
Cruzia tentaculata & 38912 \\
Didelphonema longispiculata & 38913 \\
Mathevotaenia bivittata & 38909 \\
Oligacanthorhynchus microcephalus & 38908 \\
Physaloptera mirandai & 38914 \\
Rhopalias coronatus & 38910 \\
Viannaia conspicua & 38915 \\
Viannaia pusilla & 38916 \\
\hline
\end{tabular}

